\title{
HOW SHOULD OUR LAW BOOKS BE WRITTEN?
}

American legal treatises on the common law fall into two classes-state books and books treating of the common law of all the states. State books, faithfully written, serve a useful purpose, for they are more complete than the best state digest; besides, they deal with their respective subjects from a different point of view. The digester aims to state correctly the principles decided in a case, perhaps the facts also; the writer aims to present principles in an orderly manner; in other words, to combine them into a system. Direct legal improvement is no concern of his, for he can hardly hope to modify any principle by showing how contrary it may be to that held by the courts of other states, since the maxim stare decisis still remains the strongest light in the tortuous channel of state and federal jurisprudence. Nevertheless, it is his duty to show clearly the points of similarity or dissimilarity of the decisions within his own field, thus rendering the existing system more luminous. His work, if well done, yields a true reward, for, though he cannot aspire to become directly a molder of the law, yet by reconciling seeming incongruities, or by exposing those not previously discovered, he can prepare the way for improving the law by judicial or legislative action.

The writer who attempts to unfold the common law of all the states on a particular topic has before him a very different task. If he aims to produce a work essentially exhaustive he traverses the field of comparative jurisprudence. The principal defect of many of the modern law books falling within this class is, they do not regard the subject from this point of view, are incomplete, and consequently do not possess the same authority as the older books in their day. It is true that, when Story wrote, he was not thinking of writing works on comparative jurisprudence; nevertheless it was not difficult for him to examine every decision lying within the field of his particular inquiry; in effect, therefore, he pursued this method. In any event, the reader felt assured that the subject had been presented in its completeness, hence he was justified in regarding the writer as a trustworthy guide. With the rapid increase of decisions, recent writers, with a few exceptions, despairing of attaining similar completeness, have con- 
tented themselves with presenting, as they supposed, the more important principles fortified with some references, without much or any thought of the question how the principles were regarded in different jurisdictions. The comparative method has not been observed, and so the worth of their.productions, measured by those of earlier authors, has steadily declined in usefulness and authority. Their books are often but little more than a digest of a particular subject, with a better arrangement of the principles, but without the merit even of the completeness of a digest.

An illustration may be given to show more clearly the nature of this method, and its weakness. Recently a work appeared on the subject of receivership, in which the writer stated that a foreign receiver could not sue for an unpaid subscription. The writer cited a Nebraska case to which he might have added another from the Supreme Court of Iowa. But he overlooked a large number of decisions clearly establishing the opposite rule. If a lawyer in Nebraska should seek to learn whether any rule had been declared in his state, he would discover the correct rule; while a lawyer in Massachusetts who should consult the book on a similar quest would be led astray.

Many of our modern books abound in these imperfections. Consequently there is danger in using them as authorities for new rules in states where none exist. There is no certainty that the rule found in one of them is the last rule, or is maintained by the larger number of states, for the author does not usually profess to have used the exhaustive, comparative method, but only professes that the principles stated are sustained by his citations.

Does anyone doubt the successful employment of the comparative method? Perfection is not expected, but with the excellent digests, both state and national, now existing, it is practicable to collect and compare all the cases dealing with the same matter and the different rules embedded in them. The preparation of such books, of course, requires more labor and closer study, but is within the range of achievement. Many writers, seemingly, after choosing their field dare go no further than to select such principles as can be easily fortified by adequate citations. They dare not collect all the cases pertaining to a topic, discriminate between the rules delivered, and pronounce a judgment, founded on reasons, in favor of the rule more worthy of adoption. Rather than undertake the labor of doing this, or run the risk of falling into error, they abdicate the high position they might occupy as authorities establishing legal principles in states where none exist.

Of course a writer may, notwithstanding the keenest search, 
overlook principles, or may intentionally omit them because they lie, in his opinion, outside the boundary of his field of inquiry. But whatever principles are within his ken should be examined by the light of the comparative method, for then, if his work is well done, the reader will be assured that he is in possession of the truth he is trying to learn, while by the old method he simply knows that he has learned something, the rule in one or more states, without knowing whether it is the most general or better rule that has been perfected and applied.

To this one may reply: "Cannot a judge be satisfied with the rule as disclosed by the courts of one or two states without knowing more?" Yes, sometimes they are too easily satisfied. Some courts rely largely for new rules on the decisions of the courts perhaps of a single state, much older and worthy of high regard. Again, a judge may be satisfied with the rule established by almost any decision which he believes to be based on sound reasoning. Yet how often have such precedents proved to be faulty, judged by the light of later discoveries! How often has the joy in establishing a new rule turned into regret after gaining a better knowledge from the study of other cases than those known at the time of rendering the decision.

There is, then, greater need for books based on the comparative method. The modern reviewing judge in most of the states is a hard worker with but little time for studying cases outside those mentioned in brief or argument. When one examines the great variety of cases collected in a small volume of modern reports, and considers the short time given for their presentation to the court and its subsequent study of them, he should be agreeably surprised in finding so many luminous deliverances. But he will also note great differences. And the reason often is, the luminous opinion is founded on a thoroughly prepared brief strengthened by an informing argument, while the imperfect, disappointing opinion is the outcome of reverse circumstances. Doubtless many an opinion has been prepared with the consciousness that the subject was not well understood, but the author had not more time to bestow on its preparation, while occasionally an opinion betrays a sad comprehension of the importance of the question in controversy, or the correct answer. To those who are thus in quest of knowledge a law writer who is properly qualified for his task should be a welcome helper. He ought to know more about his subject, which he has especially studied, than any judge or lawyer, and therefore can rightfully and modestly claim to be the teacher of all others. And if he has not thus mastered it, and acquired a much better under- 
standing of it than others, he ought not to add another book of the old-fashioned kind to the over-burdened literature now existing.

The writer, therefore, on comparative jurisprudence, who brings to his task proper qualifications and produces the needful kind of book will render a constantly increasing service to bar and bench, and more than regain the height formerly occupied by legal writers. If his deductions can never be as weighty with the court as were the responsa prudentium of the Roman lawyers with the prætors, yet he can always be one of the strong and welcome lights illuminating the judicial pathway. And the more complex our jurisprudence, the greater is the need of expert or special study of its different branches. Nor is there any reason for doubting the worth of the researches of any expert who truly achieves his task. Doubtless the writing of many of the state books has grown out of the inability or fear to produce those of the kind described. The cases may indeed become so numerous pertaining to a subject that no one can become master of them; but that time is not yet.

To produce a book of the highest utility on a branch of the common law, the writer can do something more than present narrowly the decisions. These are binding rules in the states where they were rendered; in other states they are simply reasons to the judicial mind. The law writer who is treating them comparatively regards them in a double aspect; for the citizen of the state wherein they were delivered they are formal declarations or rules of law, and in collecting, arranging and reproducing them the writer acts as a recorder; for the courts or citizens of other states they are not rules in any sense, but simply reasons; worthy, it may be, of conversion into rules whenever the proper occasion for doing so shall arise. Consequently a court in one state does not recognize any requirement to adopt the rules established in another state, except as evidence of the law in that state. In other regards its rules are reasons; often very weighty, fit for adoption by another jurisdiction. While the courts thus deal with the rules of other states, too often the law writer hesitates or neglects to regard them in the latter aspect, thereby impairing the usefulness of his work. He fails to sift and classify conflicting decisions, through fear perhaps that he does not understand them, and will put them into the wrong category. Of course, this criticism does not apply to all law writers; some of them clearly show a mastery of their subject, and do not fear to classify conflicting decisions and to deduce from these the better or more general rule. 
As the common law rules established in every state are only reasons in other states for establishing similar rules, why should not statutes be thus regarded and considered also by the comparative law writer? Thus in most of the states both by common law and statute the holder of a check cannot sue the drawee bank unless it has promised to pay. In four states the opposite rule prevails. The latter rule has been recently superseded by statute in several states, and doubtless the former will ultimately become universal. In several of the newer states no rule has yet been adopted, but doubtless will be in the near future. In presenting to the court in one of these states the reasons for establishing the more general rule, why should not the statutes embodying it, showing the legislative, representative will, have quite as much or more weight than the decisions of courts representing the judicial will? Is it not as clearly within the province of the law writer to present the statutes establishing or superseding a common-law rule, as the legal decisions?

Again, a common-law rule is often superseded by a statute of which the writer takes no notice. The rule has been swept away; surely this fact is worth giving to one who is trying to find out what the rule is and how generally it exists. By thus stating the rule and ignoring its supersedure, the law writer is without excuse for leading his reader astray. It is just as easy to examine statutes as reports; only more time is required to complete the enterprise. And, after all, is not this the principal reason for producing so many imperfect books, the author's unwillingness or lack of patience to devote the time needful to write better ones?

Of late, another kind of book is appearing, in which completenes's of citation is the author's goal. Such works are supposed to be especially valuable to the brief-maker as a quarry, to, which he can go and find ore. Many of the citations massed bear indirectly on the principle, yet by the method are rightfully included. Doubtless these works have a real use, but are still wanting in the comparative idea, the sifting of cases, putting them under their proper classifications and evolving from them the better rules. They may serve as authorities for the rules stated; they are still lacking in the higher critical elements.

Lastly, excellent as are many of our law schools, can they not break into new ground by dealing with a larger number of the unsettled questions than they now do? Doubtless some instructors would say: "It is our business to teach law students the leading or most general principles." But ought the work of instruction to stop with their presentation? Many of the conflicting rules are 
of frequent application, and therefore it would seem that the student ought, if possible, to have some knowledge of them. The conflict has grown out of their constant application. Cannot the comparative method be applied to the examination and presentation of many of these questions, to the obvious profit of those who attend these institutions?

Albert S. Bollos. 